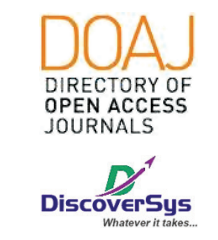

Published by DiscoverSys

\section{Karakteristik ibu hamil dengan hiperemesis gravidarum di RSUP Sanglah Denpasar tahun 2017}

\author{
Luh Putu Mahatya Valdini Putri, ${ }^{1 *}$ A. A. Gede Putra Wiradnyana, ${ }^{2}$ \\ I Made Darmayasa ${ }^{2}$
}

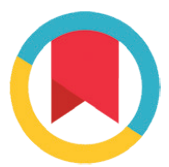

CrossMark

\title{
ABSTRACT
}

Background: Hyperemesis gravidarum is severe and over vomiting suffered as of early in pregnancy until 20 weeks of gestation. It may be harmful to the mother's health that can lead to weight loss of more than $5 \%$ and cause metabolic disorders. If it does not get proper treatment, it affects complications, even maternal and fetal deaths. Aim: The study aims to generalize the characteristic of pregnant patients who suffered hyperemesis gravidarum in Sanglah General Hospital. Method: This study is a cross sectional retrospective descriptive study with data retrieval on patient records for one year in 2017. This research was conducted at Space Cempaka Obstetrics and Medical Record Division Sanglah Hospital Denpasar.
Result and Conclusion: Pregnant women with hyperemesis gravidarum based on mother's age is highest experienced by pregnant women in the age group 20-35 years as many as 6 people (75\%). Based on maternal age, pregnant women with hyperemesis gravidarum is highest experienced by pregnant women in the first trimester as many as 5 people (62.5\%). As regard with the parity, it was highest experienced by pregnant women in the parity group nullipara as many as 4 people (50\%). Moreover, maternal education is highest academic of pregnant women who have junior high and high school education, each of them as many as 3 people (37.5\%). Based on the job status is highest experienced by pregnant women who work as many as 5 people $(62.5 \%)$.

Keywords: Hyperemesis Gravidarum, first trimester, parity

Cite This Article: Putri, L.P.M.V., Wiradnyana, A.A.G.P., Darmayasa, I.M. 2019. Karakteristik ibu hamil dengan hiperemesis gravidarum di RSUP Sanglah Denpasar tahun 2017. Intisari Sains Medis 10(2): 177-179. D0I: 10.15562/ism.v10i2.257

\section{ABSTRAK}

Hiperemesis gravidarum adalah muntah yang terjadi pada awal kehamilan sampai umur kehamilan 20 minggu, dimana terkadang muntah yang terjadi begitu hebat dan mengganggu aktivitas seharihari. Hiperemesis gravidarum bisa membahayakan kesehatan ibu yaitu dapat menyebabkan penurunan berat badan lebih dari $5 \%$ serta menyebabkan gangguan metabolisme.

Tujuan: Untuk mengetahui karakteristik pasien hyperemesis gravidarum di RSUP Sanglah Denpasar.

Metode: Penelitian ini merupakan penelitian yang bersifat deskriptif retrospektif cross sectional dengan pengambilan data pada rekam medis pasien selama satu tahun pada tahun 2017. Penelitian ini dilakukan di Ruang Cempaka Obstetri dan Bagian Rekam Medis RSUP Sanglah Denpasar.
Hasil dan Kesimpulan: ibu hamil dengan hiperemesis gravidarum berdasarkan usia ibu paling tinggi dialami oleh ibu hamil pada kelompok usia 20-35 tahun sebanyak 6 orang (75\%). Berdasarkan usia kehamilan ibu, ibu hamil dengan hiperemesis gravidarum paling tinggi dialami oleh ibu hamil pada trimester I sebanyak 5 orang (62,5\%). Berdasarkan paritas paling tinggi dialami oleh ibu hamil pada kelompok paritas nulipara sebanyak 4 orang (50\%). Berdasarkan tingkat pendidikan ibu paling tinggi dialami oleh ibu hamil yang memiliki pendidikan SMP dan SMA yaitu masing-masing sebanyak 3 orang (37,5\%). Berdasarkan status pekerjaan paling tinggi dialami oleh ibu hamil yang bekerja sebanyak 5 orang $(62,5 \%)$.
1Program Studi Pendidikan Dokter Fakultas Kedokteran Universitas Udayana

${ }^{2}$ Bag/SMF Obstetri dan Ginekologi Fakultas Kedokteran Universitas Udayana, RSUP Sanglah

*Correspondence to: Luh Putu Mahatya Valdini Putri, Program Studi Pendidikan Dokter Fakultas Kedokteran Universitas Udayana tyavaldini76@gmail.com

Diterima: $13-04-2018$

Disetujui: 08-08-2018

Diterbitkan: 01-08-2019
Kata kunci: Hiperemesis gravidarum, kehamilan trimester pertama, paritas

Cite Pasal Ini: Putri, L.P.M.V., Wiradnyana, A.A.G.P., Darmayasa, I.M. 2019. Karakteristik ibu hamil dengan hiperemesis gravidarum di RSUP Sanglah Denpasar tahun 2017. Intisari Sains Medis 10(2): 177-179. D0I: 10.15562/ism.v10i2.257

\section{PENDAHULUAN}

Kehamilan adalah pertumbuhan dan perkembangan janin intra uteri mulai sejak konsepsi dan berakhir sampai permulaan persalinan. ${ }^{1}$ Mual dan muntah adalah hal yang umum terjadi pada kehamilan. Sekitar $80 \%$ dari seluruh kehamilan disertai dengan kejadian mual dan muntah (emesis gravidarum) ${ }^{2}$ Keadaan emesis gravidarum ini dapat memberat dan berubah parah menjadi hiperemesis gravidarum. ${ }^{2}$ Hiperemesis gravidarum adalah muntah yang terjadi pada awal kehamilan sampai 
umur kehamilan 20 minggu, dimana terkadang muntah yang terjadi begitu hebat dan mengganggu aktivitas sehari-hari. Hiperemesis gravidarum berhubungan dengan cairan, elektrolit dan ketidakseimbangan asam-basa kekurangan nutrisi dan penurunan berat badan serta sering cukup parah sehingga diperlukan perawatan di rumah sakit. Gejala biasanya mulai pada 4- 8 minggu kehamilan dan berlanjut hingga 14-16 minggu kehamilan. ${ }^{3}$

Secara umum, kejadian hiperemesis gravidarum yang terjadi di seluruh dunia masih bervariasi, dimana ditemukan sebanyak dari $0.3 \%$ dari seluruh kehamilan di Swedia, 0.5\% di California, 0.8\% di Kanada, $10.8 \%$ di China, $0.9 \%$ di Norwegia, $2.2 \%$ di Pakistan dan $1.9 \%$ di Turki. Sementara itu, ditemukan sebanyak 1-3\% dari seluruh kehamilan di Indonesia. ${ }^{4-7}$ Pada $0.3-2 \%$ kehamilan terjadi hiperemesis gravidarum yang menyebabkan ibu harus dirawatinapkan. ${ }^{2}$

Berawal dari mual dan muntah yang berlebihan sehingga menyebabkan dehidrasi, tekanan darah turun dan kemudian diuresis menurun sehingga perfusi ke jaringan menurun untuk memberikan nutrisi dan mengonsumsi oksigen. Akibatnya terjadi perubahan metabolisme dari aerobik menuju ke arah anaerobik yang menimbulkan benda keton dan asam laktat, kemudian masuk ke peredaran darah sehingga terjadi asidosis metabolik. ${ }^{1}$

Hiperemesis gravidarum bisa membahayakan kesehatan ibu yaitu dapat menyebabkan penurunan berat badan lebih dari 5\% serta menyebabkan gangguan metabolisme sehingga menyebabkan komplikasi lainnya seperti dehidrasi, lemah dan kekurangan gizi. Jika tidak mendapatkan penanganan yang tepat, hiperemesis gravidarum dapat menyebabkan ikterus, ketonuria, penimbunan asam laktat, asidosis metabolik, bahkan kematian ibu dan janin. ${ }^{1}$

\section{METODE}

Penelitian ini merupakan penelitian yang bersifat deskriptif retrospektif cross sectional dengan pengambilan data pada rekam medis pasien selama satu tahun pada tahun 2017. Penelitian ini dilakukan di Ruang Cempaka Obstetri dan Bagian Rekam Medis RSUP Sanglah Denpasar selama Januari 2018-Maret 2018. Populasi penelitian adalah ibu hamil dengan hiperemesis gravidarum di RSUP Sanglah tahun 2017. Sampel penelitian adalah populasi yang memenuhi kriteria inklusi dan tidak memenuhi kriteria ekslusi. Kriteria inklusi yaitu ibu yang hamil, hamil tunggal, hamil hidup dan memiliki usia kehamilan $<20$ minggu. Kriteria eksklusi yaitu Intra Uterine Fetal Death (IUFD), mola hidatidosa, hamil ganda dan hamil dengan kelainan medis. Sampel penelitian diambil menggunakan teknik sampling nonprobability dengan menggunakan total sampling berjumlah 8 sampel. Variabel yang diteliti yaitu usia ibu, usia kehamilan ibu, paritas, pendidikan ibu dan status pekerjaan.

\section{HASIL}

Populasi ibu hamil dengan hiperemesis gravidarum di RSUP Sanglah Denpasar tahun 2017 yang digunakan sebagai sampel berjumlah 8 orang. Hasil penelitian dapat dilihat pada Tabel 1 yang menunjukkan karakteristik ibu hamil yang menderita hiperemesis gravidarum di RSUP Sanglah Denpasar tahun 2017.

Berdasarkan Tabel 1, pada tahun 2017 ibu hamil yang menderita hiperemesis gravidarum tertinggi didapatkan pada usia 20-35 tahun yaitu sebanyak 6 orang (75\%). Hasil ini sejalan dengan penelitian yang dilakukan oleh Dempi Tri Yanti di RS Muhammadiyah Palembang dengan hasil yaitu ibu hamil dengan hiperemesis gravidarum tertinggi pada usia $20-35$ tahun sebanyak 35 orang $(87,5 \%){ }^{8}$ Usia 20-35 tahun merupakan usia optimal dan aman dalam menerima kehamilan karena fisiknya stabil. Namun kembali lagi pada kondisi psikologis sang ibu, apabila usianya merupakan usia optimal namun sedang dalam kondisi stres maka hiperemesis dapat dialami oleh ibu tersebut.

Berdasarkan usia kehamilan, pada tahun 2017 ibu hamil penderita hiperemesis gravidarum ditemukan terbanyak pada trimester I, yaitu 5 orang (62.5\%). Hal ini sejalan dengan penelitian yang dilakukan oleh Yasa di RSUD Ujungberung yang menunjukkan bahwa ibu hamil dengan hiperemesis gravidarum banyak dialami oleh ibu hamil pada trimester I. ${ }^{9}$ Hal ini terjadi dikarenakan tingginya kadar hCG saat minggu-minggu awal kehamilan sehingga terjadi rangsangan mual dan muntah yang hebat. ${ }^{10}$

Pada kategori paritas, ibu hamil yang mengalami hiperemesis gravidarum paling banyak ditemukan pada nulipara dengan jumlah 4 orang (50\%). Pada penelitian yang dilakukan Safari, dari 9 responden pada paritas nulipara mayoritas mengalami hiperemesis gravidarum sebanyak 6 orang (18.8\%). Dari 19 responden pada paritas primipara, yang mengalami hiperemesis gravidarum sebanyak 16 orang (50\%). Dari 4 responden paritas multipara, tidak satupun ibu hamil yang menderita hiperemesis gravidarum. ${ }^{11}$ Hal ini sesuai dengan literatur yang menyebutkan bahwa semakin sedikit paritasnya, maka tingkat hCG makin tinggi. ${ }^{10}$

Berdasarkan pendidikan ibu, didapatkan ibu hamil dengan hiperemesis gravidarum dengan pendidikan SMP dan SMA memiliki jumlah dan persentase yang sama, yaitu masing-masing 3 orang (37.5\%). Berbeda dengan 
Tabel 1 Karakteristik ibu hamil dengan hiperemesis gravidarum di RSUP Sanglah Denpasar tahun 2017

\begin{tabular}{lcc}
\hline Karakteristik & Frekuensi & Persentase (\%) \\
\hline Usia Ibu & 1 & 12,5 \\
$<20$ tahun & 6 & 75 \\
$20-35$ tahun & 1 & 12,5 \\
$>35$ tahun & & \\
Usia Kehamilan & 5 & 62,5 \\
Trimester I & 3 & 37,5 \\
Trimester II & & \\
Paritas & 4 & 50 \\
Nulipara & 2 & 25 \\
Primipara & 2 & 25 \\
Multipara & & 37,5 \\
Pendidikan Ibu & 3 & 37,5 \\
SMP & 3 & 25 \\
SMA & 2 & 62,5 \\
$>$ SMA & & 37,5 \\
Status Pekerjaan & 5 & \\
Bekerja & 3 & \\
Tidak bekerja & &
\end{tabular}

penelitian yang dilakukan oleh Dempi Tri Yanti di RS Muhammadiyah Palembang tahun 2014 yang menunjukkan bahwa ibu hamil dengan hiperemesis gravidarum mayoritas dialami oleh ibu yang pendidikannya diatas SMA yaitu sebanyak 26 orang $(65 \%) .{ }^{8}$ Secara umum, semakin tinggi tingkat pendidikan seseorang, maka semakin banyak pula pengetahuannya akan suatu hal. Pada ibu hamil yang tingkat pendidikannya lebih rendah, informasi yang didapatkannya cenderung lebih sedikit dibandingkan dengan orang yang tingkat pendidikannya lebih tinggi sehingga kurang tahu bagaimana cara merawat kehamilan dengan baik.

Dilihat dari status pekerjaan, ditemukan bahwa ibu hamil dengan hiperemesis gravidarum memiliki jumlah dan persentase tertinggi pada status pekerjaan bekerja yaitu sebanyak 5 orang (62.5\%). Hasil penelitian ini tidak sejalan dengan penelitian yang dilakukan oleh Dempi Tri Yanti yang menunjukkan bahwa ibu hamil yang mengalami hiperemesis gravidarum kebanyakan dialami oleh ibu rumah tangga (tidak bekerja) yaitu sebanyak 31 orang (77.5\%). ${ }^{8}$ Perbedaan hasil ini dapat terjadi karena tergantung kondisi psikologis yang ibu hamil alami, baik yang bekerja maupun yang tidak bekerja.

\section{SIMPULAN}

Ibu hamil dengan hiperemesis gravidarum di RSUP Sanglah Denpasar berdasarkan usia ibu paling tinggi dialami oleh ibu hamil pada kelompok usia 20-35 tahun sebanyak 6 orang (75\%). Berdasarkan usia kehamilan ibu, hiperemesis gravidarum paling tinggi dialami oleh ibu hamil pada trimester I sebanyak 5 orang (62.5\%). Dilihat dari paritas, hiperemesis gravidarum paling tinggi dialami oleh ibu hamil pada kelompok paritas nulipara sebanyak 4 orang (50\%). Pada kategori pendidikan ibu, hiperemesis gravidarum paling tinggi dialami oleh ibu hamil yang memiliki pendidikan SMP dan SMA yaitu masing-masing sebanyak 3 orang (37.5\%). Berdasarkan status pekerjaan, hiperemesis gravidarum paling tinggi dialami oleh ibu hamil yang bekerja sebanyak 5 orang $(62.5 \%)$.

\section{DAFTAR PUSTAKA}

1. Manuaba, I. B. G., Manuaba, I. A. C. \& Manuaba, I. B. G. F. Hiperemesis Gravidarum. Dalam: Pengantar Kuliah Obstetri. Jakarta: EGC; 2007: 396-400.

2. McCarthy, F.P., Khashan,A.S., North, R.A.,Moss-Morris, R., Baker, P. N., Dekker, G., Poston, L. \& Kenny, L.C. A prospective cohort study investigating associations between hyperemesis gravidarum and cognitive, behavioural and emotional well-being in pregnancy. PLoS One. 2011; 6(11): $1-7$.

3. Veenendaal, M. V. E., Van Abeelen, A. F. M., Painter, R. C., Van Der Post, J. A. M. \& Roseboom, T. Consequences of hyperemesis gravidarum for offspring: A systematic review and meta-analysis. Int J Obstet Gynaecol. 2011; 118(11): 1302-13.

4. Hanretty, K. P. 2008. Obstetrics Illustrated. Philadelphia: Churchill Livingstone, Inc.

5. Prawirohardjo, S. \& Wiknjosastro, H. Hiperemesis Gravidarum. Dalam: Ilmu Kebidanan. Jakarta: Yayasan Bina Pustaka Sarwono Prawirohardjo; 2002: 275-280.

6. Zhang, Y., Cantor, R. M., MacGibbon, K., Romero, R., Goodwin, T. M., Mullin, P. M., \& Fejzo, M. S. Familial aggregation of hyperemesis gravidarum. Am J Obstet Gynaecol. 2011; 204(3): 230.e1-230.e7.

7. Mullin, P. M., Bray, A., Schoenberg, F., MacGibbon, K.W., Romero, R., Goodwin, T. M., Fejzo, M. S. Prenatal exposure to hyperemesis gravidarum linked to increased risk of psychological and behavioral disorders in adulthood. Journal of Developmental Origins of Health and Disease. 2011; 200-4.

8. Yanti, D. T. Gambaran Karakteristik Ibu Hamil dengan Hiperemesis Gravidarum di Rumah Sakit Muhammadiyah Palembang Tahun 2014. Jurnal Harapan Bangsa. 2015; 3(1): 33-34.

9. Yasa, A. R. A. C. Hubungan Antara Karakteristik Ibu Hamil dengan Kejadian Hiperemesis Gravidarum di RSUD Ujungberung pada Periode 2010-2011. [Skripsi]. Bandung: Universitas Islam Bandung. 2012: 29-30.

10. Arisman, M. B. Hiperemesis Gravidarum. Dalam: Gizi dalam Daur Kehidupan: Buku Ajar Ilmu Gizi. Edisi 2. Jakarta: EGC; 2010: 27-9.

11. Safari, F. R. N. Hubungan Karakteristik dan Psikologis Ibu Hamil dengan Hiperemesis Gravidarum di RSUD H. Abd. Manan Simatupang Kisaran. Wahana Inovasi. 2017; 6(1): 205-9.

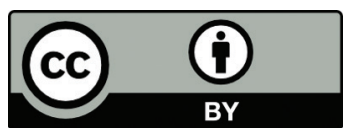

This work is licensed under a Creative Commons Attribution 